\title{
On the Essence and Development Strategy of Vocational College at Undergraduate Level
}

\begin{abstract}
Jian Zhou*
Department of computer, Wuhan polytechnic, Wuhan 430074, China

*Corresponding author. Email: 1516035655@qq.com

ABSTRACT

The establishment of vocational colleges at the undergraduate level is the inevitable outcome of China's economic and social development. China should adapt to the development trend of world vocational education and the need of China's economic development to develop vocational colleges at undergraduate level. At present, there are some limitations in people's understanding of vocational colleges at the undergraduate level, which limit the development of vocational colleges at the undergraduate level. This article will describe the nature of undergraduate vocational college and the development strategy of undergraduate vocational college.
\end{abstract}

Keywords: Undergraduate level, Vocational colleges, Essence of Higher Vocational Undergraduate, Development strategy.

\section{INTRODUCTION}

Undergraduate vocational education is the objective demand of China's social and economic industrial development and the common trend of higher education differentiation and rationalization in the second half of the 20th century. In 2014, the State Council issued the Decision on Accelerating the Development of Modern Vocational Education, which mentioned "exploring and developing vocational education at the undergraduate level" for the first time, and regarded it as one of the important measures to develop higher vocational education and build a modern vocational education system. In November 2018, the Fifth Session of the Commission for Deepening Overall Reform of the CPC Central Committee deliberated and adopted the Implementation Plan for the National Vocational Education Reform, which clearly stated the reform task of "carrying out pilot vocational education at the undergraduate level". Then in May 2019, the Ministry of Education approved 15 "vocational colleges" as the first batch of pilot vocational education schools at the undergraduate level. In January 2020, the Ministry of Education announced the second batch of six newly upgraded "vocational universities". The development policy of China's vocational undergraduate course is the forerunner and imperative. The key to run the vocational undergraduate course well is to grasp the type structure of the undergraduate course education and put the vocational undergraduate course in the position of the whole undergraduate course education. Undergraduate vocational college is another type of undergraduate with the characteristics of "same level and different kind". This undergraduate is not the other undergraduate. It is an irreplaceable type of undergraduate education. Only by making clear the boundary and fixing the position, can we give full play to the social function that vocational undergraduate should have.

\section{THE DEVELOPMENT OF HIGHER VOCATIONAL COLLEGE UNDERGRADUATES IS NOT ONLY THE NECESSITY OF THE TIMES, BUT ALSO THE NECESSITY OF HISTORY}

\subsection{Undergraduate Vocational College is the Inevitable Outcome of Economic and Social Development to the Present Age}

Undergraduate vocational college is the inevitable outcome of economic and social development to the present age. The change of labor demand structure in the new era urgently calls for the improvement of education structure. In August 2019, at a press conference on the performance of the national economy, the State Information Office pointed out that in the first half of 2019, China's industrial added value grew by $5.8 \%$ year on year, and the added value of high-tech manufacturing 
industry grew by $8.7 \%$ year on year, 2.9 percentage points faster than that of all industries above the designated size. High-tech has become an important driving force to support the economy. Innovative breakthroughs in digital and intelligent core technologies drive industrial optimization and upgrading and the overall jump in productivity, but also change the pattern and demand of the original labor force. In the era of intellectualization, the original bureaucratic work system has undergone a fundamental change to a flat and networked work system. The complexity of work has increased, and the form of work organization has changed in essence. The mainstream production mode has changed from "mass production" to "customized production" and "flexible" production. Under this new mode of production, the structure of labor demand has undergone profound changes, and a large number of regular labor has been replaced by machines, which requires the ability structure of technical skills and talents to be extended to a certain depth and breadth, that is, to pay equal attention to practical ability and theoretical knowledge, and to compound technical ability and engineering ability. Due to this changing trend, the job tasks are becoming more and more broad and complex, which directly determines that the vocational ability of the talents trained by the original vocational colleges is not sufficient, and these vocational abilities are impossible to be cultivated through ordinary undergraduate education. It can be seen that China's talent supply structure is facing the dual contradiction of talent "level" and talent "type". The shortage of highlevel technical and skilled personnel has become a bottleneck problem restricting the economic development of our country. In this context, the original educational structure obviously cannot fully meet the profound changes of economy and society and the rapid development of technology to the new demand for education. According to the basic meaning of Spencer's explanation of organic "functionalism", educational structure directly affects the exertion of educational function. At present, on the one hand, the upward expansion of vocational education needs to be met; On the other hand, it is imperative to rationalize the structure of higher education types.

\subsection{Developing Vocational Education at Undergraduate Level Meets People's Needs}

Developing vocational undergraduate education is an inevitable response to alleviate education anxiety and employment anxiety and satisfy the people's pursuit of a more satisfactory education. In recent years, with the expansion of employment scale, the problem of difficult employment for college graduates has become increasingly prominent. According to MyCOS "2019 Chinese College Students Employment Report" survey, the employment rate of undergraduate students continues to decline slowly, while the employment rate of vocational college students increases steadily. Because the general higher education training system is not closely related to the actual job, there is widespread employment anxiety of "unemployment upon graduation". The effective way to alleviate this problem is to guide them to be distributed into the vocational education and training system, so that their learning can be used to effectively solve the employment problem. In addition to employment anxiety, increasingly serious education anxiety is also a very prominent social problem at present. Under the current educational system and social and cultural atmosphere, students usually choose to obtain academic degrees and degrees if they want to gain high social recognition. The people's pursuit of education has changed from "being able to learn" to "being eager to learn". Therefore, it has become the main contradiction to let individuals obtain suitable education according to their own wishes in a variety of choices and truly solve the problem of "enjoying fair and quality education". Vocational undergraduate education, providing more diversified educational options and conferencing corresponding technical degrees, can not only alleviate the increasingly serious social education anxiety, but also provide more educational choices and learning freedom for parents and students, so that higher education can truly change from "selective education" to "selective education".

\subsection{Developing Vocational Education at Undergraduate Level is a Necessary Measure for the Current Development Trend of Vocational Education and Higher Education}

Developing vocational education at undergraduate level is a necessary measure for the development trend of vocational education and higher education in today's world. Higher vocational education and professionalization of higher education are the common trend of international education development in the $21 \mathrm{st}$ century. Taking a look at the development history of vocational education in the world, under the dual influence of industrial transformation and education popularization, post-war industrialized countries have formed a system of application-oriented talents training with national characteristics. In the 1990s, as developed countries entered the stage of higher education popularization one after another, higher vocational education aimed at cultivating practical and applied talents emerged day by day, including German specialized universities, British multi-disciplinary universities and Japanese short-term universities. In the 21 st century, the development of science and technology has changed from the multiplication of knowledge based on differentiation to the globalization of science and technology, economy and intelligence based on synthesis. The rapid and rapid development of technology and its trend of integration and complexity make the technical content of professional job tasks continuously improve. 
Therefore, countries begin to vigorously develop vocational undergraduate education to meet the demand for high-level technical skills. Vocational college education at undergraduate level has become an indispensable part of modern vocational education system in developed countries. From the reality of China, the rapid development of economic and social industries has clearly sent a signal, that is, the industry has an urgent need for high-level technical skills who have mastered complex technical knowledge. However, there are only middle level and higher specialized level vocational education in the vocational education system of our country, and the vocational education of undergraduate level and above is still a blank field. Therefore, based on the current situation of our country, the establishment of undergraduate vocational education in accordance with the national conditions not only follows the development law of education itself, but also conforms to the common trend of international education development.

\section{UNDERSTANDING OF VOCATIONAL EDUCATION AT UNDERGRADUATE LEVEL}

With the development of higher education in China entering the stage of popularization and popularization, most institutions of higher learning still only tend to the single development path of elitism and academicization, which cannot meet the needs of multi-type and multilevel talent cultivation. The classification and orientation of higher education has become an urgent problem for the development of higher education in China. According to the classification of international education standards and the actual situation of our country, some scholars divide Chinese institutions of higher learning into three types: comprehensive research type, professional type (applied type) and vocational and technical type (or skill type). ${ }^{[1]}$ In 2017, the Opinions on the Establishment of Institutions of Higher Learning during the 13th FiveYear Plan Period issued by the Ministry of Education explored and constructed a higher education classification system, which divided China's higher education into three types: research-oriented, application-oriented and vocational and skilled. The development of higher vocational education has been affirmed at the theoretical and policy levels, but in practice, China's higher vocational education has only stayed at the junior college level for a long time, and has not been involved in the undergraduate level. There is insufficient awareness of the importance and necessity of the development of vocational undergraduate education, and there is some controversy about whether to carry out vocational undergraduate education. Some scholars even put forward that vocational education does not have to have the same level of education as ordinary education. [2] along with our country vocational education modernization is accelerated, and since 2019 the advancement of job of undergraduate course level vocational education pilot professional undergraduate course in improving the modern vocational education system, consolidate the position type of vocational education, to meet the demands of market and the personal development importance is taken seriously increasingly, the development of ${ }^{[3]}$ professional undergraduate course, will be included in the undergraduate level vocational education system has basically formed a consensus.

\section{DEVELOPMENT STRATEGY OF HIGHER VOCATIONAL EDUCATION AT UNDERGRADUATE LEVEL}

\subsection{The Talent Training Objective of Undergraduate Vocational Education is the First Issue to be Considered in the Development of Undergraduate Vocational Education}

What kind of people to cultivate is the first issue to be considered in the development of vocational education at the undergraduate level, so the formulation of personnel training objectives is particularly important. To conform to the purpose of education and vocational education in our country overall goal, promote the comprehensive development, social occupational demand oriented, highlight the characteristics of technology application principles, to vocational education and ordinary undergraduate course and specialized subject undergraduate level talented person the difference between the types and levels of responsibility for the premise, with economic development and the progress of science and technology requirement for personnel specifications and quality as the basis, to talents' knowledge, ability and quality requirements for personnel training goal set basic connotation. ${ }^{[4]}$ Scholars have different expressions about the specific objectives of talent training in vocational education at undergraduate level, such as technical talents at undergraduate level, "teacher" talents, senior technical applied talents, high-level technical talents, compound talents, and talents with industrial and sustainable development ability. Exploring its connotation, it is not difficult to find that its talent training objectives have a common directivity, that is, they not only reflect the academic nature of undergraduate education, but also reflect the application of vocational education, which can well integrate the two.

\subsection{The Curriculum System of Undergraduate Vocational Education is the key of Undergraduate Vocational Education}

The curriculum system of undergraduate vocational education is the key to embody the characteristics of undergraduate vocational education. Some scholars believe that vocational education at undergraduate level 
should establish a course system that pays attention to context and is based on process, adhere to work orientation, develop teaching syllabus based on work process, and impart knowledge and skills by setting context in specific work links. Some scholars believe that different professions correspond to different learning fields, so curriculum development should be guided by career process and arranged flexibly. Some scholars put forward that the curriculum setting mode should be integrated and modularized, that the course offering sequence should be designed according to the requirements of the post/post group on the talents, that theoretical teaching and practical training can be carried out alternately, and that the curriculum setting should emphasize both theory and practice. Other scholars believe that the value orientation of vocational education at the undergraduate level is to promote industrial development, curriculum setting is based on the ability target system, and curriculum construction follows the process of "simple - medium - complex". They propose a modular curriculum structure with "general education + core professional courses + technical knowledge + practice courses" as the core. On the whole, the curriculum system of vocational education at undergraduate level should focus on the value orientation and promote the development of industry. Curriculum development, adhere to the work/career process-oriented; In terms of course content, courses are arranged according to the requirements of different professions, and both theory and practice are emphasized. The course sequence is based on the work flow of the post and follows the rule from easy to difficult. In the course of concrete implementation, theory -- practice -- theory, or practice -- theory -- practice can be carried out alternately. In addition, some scholars in Taiwan's vocational education courses for research, undergraduate level that its objective present practical orientation, curriculum development and the consummation by participating, curriculum development both individual and social needs, to design curriculum system for ability training, at the same time open across the professional degree program and the last mile "program" in order to realize the combination of education and industry, ${ }^{[5]}$ for the mainland undergraduate level vocational education curriculum system construction has a certain reference value.

\section{CONCLUSION}

The higher vocational education at the undergraduate level is different from the ordinary undergraduate level. At present, China's economy is in the stage of rapid development, so it is imperative to develop the vocational education at the undergraduate level. Based on this background, it effectively improves the career planning level and career development efficiency of undergraduate students. Especially under the premise of China's rapid economic development, vocational education reform at the undergraduate level has been carried out more actively.

Moreover, it effectively highlights the characteristics of the overall education and teaching work, including personal development guarantee, personal growth guarantee, personal accomplishment guarantee and personal quality guarantee for students. Based on this, it not only drives the future career development of undergraduate students, but also accelerates the process of social economic development and construction, and cultivates the social competitiveness of undergraduate students.

\section{REFERENCES}

[1] United Nations Educational, Scientific and Cultural Organization. The international education standard classification ISCED2011 [EB/OL]. (2013-10-07) [2020-10-28].

http://uis.unesco.org/sites/default/files/documents/i sced-2011-ch.pdf.

[2] Zhou Tingyong, Xiong Libo. The mission change of western universities and its historical effect [J]. Modern University Education, 2009, (02) :49.

[3] Wu Daguang. The Conflict and Choice between Rationalism and Utilitarianism -- Theoretical Reflection on the Evolution of Western Higher Education Thought [J]. Higher Education Research, 1989, (04) :82-83.

[4] Hao Tiancong, Zhuang Xizhen. A new approach to the development of vocational education in China [J]. China Vocational and Technical Education, 2015(30): 80-84.

[5] Tu XiangHui. An Analysis of the Training Objectives of Higher Vocational Education at Undergraduate Level $[\mathrm{J}]$. China Vocational and Technical Education, 2012(27):15-20. 